\title{
A new species of Cordia (Cordiaceae) for the state of Minas Gerais, Brazil
}

\author{
Elsie Franklin Guimarães ${ }^{1}$, Neusa Taroda Ranga ${ }^{2}$ \& José Iranildo Miranda de Melo ${ }^{3 *}$ \\ ${ }^{1}$ Instituto de Pesquisas Jardim Botânico do Rio de Janeiro, Herbário, Rua Pacheco Leão, 915, CEP 22460-030 Rio de Janeiro, \\ Rio de Janeiro, Brazil; eguimar@jbrj.gov.br \\ ${ }^{2}$ Instituto de Biociências, Letras e Ciências Exatas, Universidade Estadual Paulista Júlio de Mesquita Filho, Rua Cristóvão Colombo, \\ 2265, Jd. Nazareth, CEP 15054-000 São José do Rio Preto, São Paulo, Brazil; neusatr@ibilce.unesp.br \\ 3"Universidade Estadual da Paraíba, Centro de Ciências Biológicas e da Saúde, Departamento de Biologia, Avenida das Baraúnas, \\ 351, Campus Universitário, CEP 58429-500 Campina Grande, Paraíba, Brazil; tournefort@gmail.com
}

\begin{abstract}
Guimarães, E.F., Ranga, N.T. \& Melo, J.I.M. 2016. A new species of Cordia (Cordiaceae) for the state of Minas Gerais, Brazil. Anales Jard. Bot. Madrid 73(1): e034.

A new species of the genus Cordia (Cordiaceae), C. kuhlmannii E.F. Guim., N.T. Ranga \& J.I.M. Melo, for the state of Minas Gerais, Brazil is described and illustrated. The species, belonging to the section Gerascanthus is characterized mainly by irregular calyx lobes, corolla with narrow tube, stamens with glabrate bases and long branches of the style.
\end{abstract}

Keywords: Boraginales, Cordiaceae, Gerascanthus, South America, taxonomy.

\section{INTRODUCTION}

The generic limits of Cordia L. were recently reviewed by Gottschling \& Miller (2006), who subordinated the species of Auxemma Miers and Patagonula L. to this genus, and by Miller \& Gottschling (2007), who revalidated Varronia P. Browne.

Despite the segregation of species of Varronia, Cordia is still the most representative genus of Cordiaceae, including approximately 250 species distributed in tropical and subtropical regions, being particularly well represented in the American continent (Miller \& Gottschling, 2007).

The genus Cordia sensu lato encompasses 350 species (Taroda \& al., 2012) and, in the new world, its main center of taxonomic diversification is Brazil, with 52 species, of which 28 are endemic to the flora of the country (Melo $\&$ al., 2014).

Regarding species of Cordia most are trees or shrubs, with branches showing simple or stellate trichomes; alternate, simple leaves; flowers grouped in a paniculate or thyrsoid inflorescence, axillary or terminal, lax or congested, generally with tubular to campanulate calyx, externally smooth or costate, 3-10-dentate, corolla funnel-shaped or hypocrateriform, white, yellow or orange, with included or excluded stamens and the ovary bilocular with 2 ovules per locule, terminal style split at the apex, with 4 stigmatic branches; the fruit is a drupe-like, carrying 1 seed, with persistent calyx.

The genus Cordia has been revised for Brazil in its traditional concept (Taroda \& Gibbs, 1986a; 1986b; 1987) as a whole or, in the sensu stricto, in part (Stapf, 2010). More recently, a revision of Cordia sect. Gerascanthus P. Browne

\section{Resumen}

Guimarães, E.F., Ranga, N.T. \& Melo, J.I.M. 2016. Una nueva especie de Cordia (Cordiaceae) para el estado de Minas Gerais, Brasil. Anales Jard. Bot. Madrid 73(1): e034.

Se describe e ilustra una nueva especie del género Cordia (Cordiaceae), C. kuhlmannii E.F. Guim., N.T. Ranga \& J.I.M. Melo, para el estado de Minas Gerais, Brasil. La especie pertenece a la sección Gerascanthus y es caracterizada, principalmente, por presentar los lóbulos del cáliz irregulares, la corola con tubo estrecho, los estambres glabros en la base y las ramas de los estilos largas, de cerca de $5 \mathrm{~mm}$.

Palabras clave: América del Sur, Boraginales, Cordiaceae, Gerascanthus, taxonomía.

was elaborated by Miller (2013). According to this same author (2013), their species are characterized by flowers with tubular, ribbed calyces and, marcescent corollas surrounding the developing fruit, aiding in its wind dispersal, and fruits ellipsoid, single-seeded, with a fibrous wall. However, a new species, C. kublmannii E.F. Guim., N.T. Ranga \& J.I.M. Melo, belonging to Cordia sect. Gerascanthus is here described and illustrated for the state of Minas Gerais, southeastern Brazil, being recognized for lobes of calyx irregular, corolla with narrow tube, stamens with glabrate base, and long style branches.

\section{MATERIAL AND METHODS}

Exsiccatae deposited in the major herbaria of the state of Rio de Janeiro were analyzed: GUA, HB, R, RB, RFA and RUSU (Thiers, 2014). For the taxonomic description, the works of Hickey (1974) and Weberling (1995) were consulted for the standardization of morphological terminology. Data on geographical distribution, habitat and flowering are presented, in addition to images containing the species diagnostic characters, and also an identification key of the Brazilian representatives of the section Gerascanthus, based on specimens of the herbaria of the state of Rio de Janeiro.

\section{RESULTS AND DISCUSSION}

The section Gerascanthus comprises 23 species distributed in the Neotropics (Miller, 2013) and, of these, six species have been recorded so far for Brazil (Miller, 2013; Melo \& al., 2014). According to Stapf (2010), phylogenetic 
Table 1. Comparative features for Brazilian species of Cordia sect. Gerascanthus.

\begin{tabular}{|c|c|c|c|c|c|c|c|}
\hline Species feature & C. alliodora & C. glabrata & C. goeldiana & C. insignis & C. kuhlmannii & C. latiloba & C. trichotoma \\
\hline Trichomes types & $\begin{array}{l}\text { Simple and } \\
\text { stellate }\end{array}$ & Simple & Simple & Simple & Simple & Simple or absent & Stellate \\
\hline Calyx (form) & $\begin{array}{l}\text { Tubular- } \\
\text { cylindrical }\end{array}$ & $\begin{array}{l}\text { Tubular- } \\
\text { cylindrical }\end{array}$ & Campanulate & $\begin{array}{l}\text { Tubular- } \\
\text { cylindrical }\end{array}$ & Campanulate & Campanulate & $\begin{array}{l}\text { Tubular- } \\
\text { cylindrical }\end{array}$ \\
\hline Calyx (base) & Acute & Acute & Acute & Acute & $\begin{array}{l}\text { Obtuse or } \\
\text { rounded }\end{array}$ & Acute & Acute \\
\hline Calyx & Evidently costate & Evidently costate & $\begin{array}{l}\text { Smooth or } \\
\text { slightly costate }\end{array}$ & Evidently costate & $\begin{array}{l}\text { Smooth or } \\
\text { slightly costate }\end{array}$ & $\begin{array}{l}\text { Smooth or } \\
\text { slightly costate }\end{array}$ & $\begin{array}{l}\text { Evidently } \\
\text { costate }\end{array}$ \\
\hline Calyx (length) & $5-7.5 \mathrm{~mm}$ & $9-13 \mathrm{~mm}$ & $7-13 \mathrm{~mm}$ & $17-24 \mathrm{~mm}$ & $12-15 \mathrm{~mm}$ & $10-13 \mathrm{~mm}$ & $7-10 \mathrm{~mm}$ \\
\hline $\begin{array}{l}\text { Corolla (lobes } \\
\text { form) }\end{array}$ & Elliptic, oblong & Elliptic, oblong & Elliptic, oblong & Oblong & $\begin{array}{l}\text { Triangular- } \\
\text { rhombic }\end{array}$ & $\begin{array}{l}\text { Triangular- } \\
\text { rhombic }\end{array}$ & Elliptic, oblong \\
\hline $\begin{array}{l}\text { Corolla (lobes } \\
\text { measurements) }\end{array}$ & $6 \times 3 \mathrm{~mm}$ & $10 \times 15 \mathrm{~mm}$ & $\begin{array}{l}11-17 \times 5.5- \\
8.5 \mathrm{~mm}\end{array}$ & $11 \times 11 \mathrm{~mm}$ & $9-15 \times 12-13 \mathrm{~mm}$ & $10 \times 11 \mathrm{~mm}$ & $\begin{array}{l}9-11 \times 4- \\
7.5 \mathrm{~mm}\end{array}$ \\
\hline Corolla (length) & $11-14 \mathrm{~mm}$ & $24-34 \mathrm{~mm}$ & $22.5-32 \mathrm{~mm}$ & $34-52 \mathrm{~mm}$ & $35-40 \mathrm{~mm}$ & $27-35 \mathrm{~mm}$ & $12-24 \mathrm{~mm}$ \\
\hline Stamen (length) & $5-5.5 \mathrm{~mm}$ & $5.5-6 \mathrm{~mm}$ & $5-12 \mathrm{~mm}$ & $10-11 \mathrm{~mm}$ & 9-10 mm & $10-11 \mathrm{~mm}$ & $10-11 \mathrm{~mm}$ \\
\hline $\begin{array}{l}\text { Stamen } \\
\text { (filaments) }\end{array}$ & Pilose & Pilose & Pilose & Pilose & Glabrate & Pilose & Pilose \\
\hline Style (base) & Slender & Slender & Slender & Slender & $\begin{array}{l}\text { With discoid } \\
\text { thickening }\end{array}$ & Slender & Slender \\
\hline $\begin{array}{l}\text { Style branches } \\
\text { (length) }\end{array}$ & $2-3 \mathrm{~mm}$ & $\leq 0.8 \mathrm{~mm}$ & $\begin{array}{l}\text { Sessile or } \\
\leq 0.8 \mathrm{~mm}\end{array}$ & $\leq 0.8 \mathrm{~mm}$ & $4-5 \mathrm{~mm}$ & $1-1.3 \mathrm{~mm}$ & $5-7 \mathrm{~mm}$ \\
\hline
\end{tabular}

studies indicate that the section is monophyletic, being well supported by morphological and molecular data.

In general its species are trees, with petiolate leaves, blade glabrous or with simple or stellate trichomes, margin entire, venation brochidodromous, leathery except for the species described here, which shows a membranous to papery blade. The flowers are gathered in large paniculate lax inflorescences, the calyces are cylindrical and narrow in most species, distinctly costate or, less often, campanulate with regular or irregular lobes and the corolla is showy, white, except $C$. insignis, which is brownish to reddish.

Key to the Brazilian species of section Gerascanthus (Cordiaceae: Cordia):

1. Calyx campanulate, smooth or slightly costate 2

1. Calyx tubular-cylindrical, narrow, evidently costate .. 4

2. Lobes of calyx irregular; corolla with narrow tube; stamens with glabrous filaments; style presenting base discoid thickened; long style branches, ca. $5 \mathrm{~mm}$ long

C. kuhlmannii

2. Lobes of calyx regular; corolla with wide tube; stamens with pilose filaments; style without base discoid nor thickened; short style branches, smaller than $5 \mathrm{~mm}$ long 3

3. Lobes of corolla with obtuse or retuse apex C. goeldiana
3. Lobes of corolla with acute apex ........... C. latiloba

4. Leaf blade with stellate trichomes on both sides ....... 5

4. Leaf blade glabrous or with simple trichomes on both sides 6

5. Corolla tube up to the base of stamens less than $5 \mathrm{~mm}$ long; corolla lobes $3.5-5 \mathrm{~mm}$ long C. alliodora

5. Corolla tube up to the base of stamens greater than 5 $\mathrm{mm}$ long; corolla lobes greater than $5 \mathrm{~mm}$ long C. trichotoma

6. Tube of the corolla exceeding the calyx length, corolla 3.5 to $5.2 \mathrm{~mm}$ long C. insignis

6. Tube of the corolla equal or shorter than the calyx, corolla $2-3 \mathrm{~cm}$ long C. glabrata

Cordia kuhlmannii E.F. Guim., N.T. Ranga \& J.I.M. Melo, sp. nov. Iconography: Fig. 1.

TYPE: [Brazil.] Minas Gerais, Córrego do Capim, Figueira, Rio Doce, 10 October 1930, J.G. Kublmann 339 (holotype, RB).

Cordia goeldiana affinis sed, a qua praecipue differt calyx tubuloso-cylindrico, angustus, manifeste costatus, lobis irregularibus praeditus, corolla tubo angusto, stamina ad basin glabra et rami stylorum ca. $5 \mathrm{~mm}$ quam corolla longiores. 


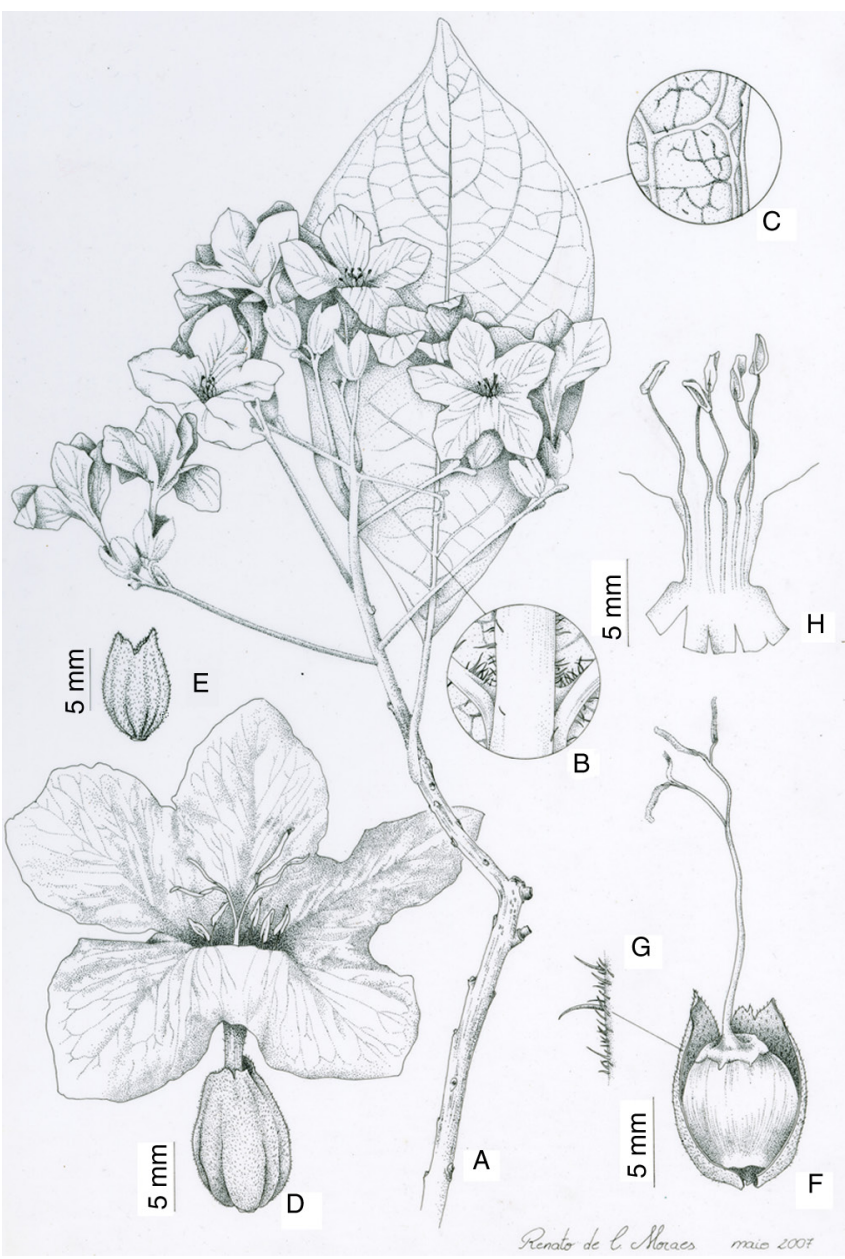

Fig. 1. Cordia kuhlmannii. A, reproductive branch; B, detail of the indumentum of the branch; $\mathbf{C}$, detail of the foliar venation; $\mathbf{D}$, flower; $\mathbf{E}$, calyx; $\mathbf{F}$, calyx showing the gynoecium; $\mathbf{G}$, detail of the indumentum of the outer portion of the calyx; $\mathbf{H}$, corolla showing the androecium. Drawn by Renato de C. Moraes.

Tree, 10-15 m high, striated branches. Leaves peciolate, petiole 2-3.5 cm long; blade $14-16 \times 5.5-10.5 \mathrm{~cm}$, elliptic, glandulous, pubescent to glabrescent, with simple trichomes on primary and secondary veins, sometimes forming tufts in the vein axils, acute to decurrent base, obtuse or rarely acute apex, membranous to papery. Inflorescence paniculate, ferruginous, tomentose, wide, lax rachis. Flowers ca. $3.9 \mathrm{~cm}$ long. Calyx 1.2$1.5 \times 0.7-0.9 \mathrm{~cm}$, campanulate, irregularly lobed, slightly costate to the apex, sometimes to the middle, externally tomentose, internally pubescent. Corolla $3.0-3.5 \mathrm{~cm}$ long; tube ca. $2.2 \mathrm{~cm}$ long; lobes 0.9-1.5 ×1.0-1.3 cm, ovoid, triangular, rhombic, glabrous, acute; stamens ca. $1 \mathrm{~cm}$ long, glabrous filaments; ovary 1.2-1.5 $\times 0.5-0.7 \mathrm{~cm}$, globose to elliptical, glabrous; style ca. 1.5 $\mathrm{cm}$ long, filiform, branches $4-5 \mathrm{~mm}$ long, presenting base thickened, discoid, similar to a stylopodium. Fruit not observed.

Distribution and habitat. The locality where the type specimen was collected (Figueira, Córrego do Capim, Rio Doce), over 80 years ago, currently corresponds to the city of Governador Valadares, formerly named as District of Santo Antonio da Figueira (IBGE, 2014). The species is known only from the type specimen, and for this reason it is considered endemic to the state of Minas Gerais.

Conservation status. Cordia kublmannii is probably endemic to Minas Gerais, considering that so far it is known only from the type specimen collected in 1930. Since there are no other records for the species in the consulted herbaria, it may be classified in the ED category (endangered) according to the criteria of the International Union for Conservation Nature (IUCN, 2001).

This species fits into the section Gerascanthus for possessing a marcescent corolla during fructification. Cordia kublmannii is morphologically similar to C. latiloba and C. goeldiana, which also possess a campanulate calyx. However, it differs from the above mentioned species by having an urceolate calyx, i.e., with inflated base and narrow at the apex, as well as glabrous filaments at the base and the presence of a discoid expansion at the style base, similar to a stylopodium. According to Kuhlmann (in sched.), this tree is popularly called laurel and the wood was used in the manufacture of doors. The features of Brazilian species of Cordia section Gerascanthus are comparatively presented in Tab. 1.

\section{ACKNOWLEDGEMENTS}

J. I. M. Melo thanks the National Council of Scientific and Technological Development $(\mathrm{CNPq})$ the award of Research Productivity Grant (PQ-2 Proc. n. 302751/2012-2). To Dr. Rafaela Campostrini Forzza, Curator of the Herbarium of the Botanical Garden of Rio de Janeiro (RB), appreciation is extended for the loan of collections for this study.

\section{REFERENCES}

Gottschling, M. \& Miller, J.S. 2006. Clarification of the taxonomic position of Auxemma, Patagonula, and Saccellium (Cordiaceae, Boraginales). Systematic Botany 31: 361-367. http://dx.doi.org/10.1600 1036364406777585919

Hickey, L.J. 1974. Clasificación de la arquitectura de las hojas de dicotiledóneas. Boletín de La Sociedad Argentina de Botánica 16: 1-26.

IBGE. 2014. Instituto Brasileiro de Geografia e Estatística. Cidades. Minas Gerais: Governador Valadares: Histórico. http://cidades.ibge.gov.br/ painel/historico.php? codmun $=312770$

Melo, J.I.M., Cavalheiro, L., Stapf, M.N.S. \& Vieira, D.D. 2014 Boraginaceae. In: Forzza, R.C. (Orgs.), Lista de Espécies da Flora do Brasil. Jardim Botânico do Rio de Janeiro, Rio de Janeiro. http://floradobrasil.jbrj.gov.br/jabot/floradobrasil/FB64

Miller, J.S. 2013. A revision of Cordia section Gerascanthus (Boraginales: Cordiales). Journal of the Botanical Research Institute of Texas 7:55-83. http://dx.doi.org/10.1078/0367-2530-00120

Miller, J.S. \& Gottschling, M. 2007. Generic classification in Cordiaceae (Boraginales): Resurrection of the genus Varronia P. Br. Taxon 56: 163-169.

Stapf, M.N.S. 2010. Nomenclatural notes on Varronia (Boraginaceae s.l.) in Brazil. Rodriguésia 61: 133-135. http://dx.doi.org/10.1111/curt.12106

Taroda, N. \& Gibbs, P.E. 1986a. Studies on the genus Cordia L. (Boraginaceae) in Brazil. 1. A new infrageneric classification and conspectus. Revista Brasileira de Botânica 9: 31-42.

Taroda, N. \& Gibbs, P.E. 1986b. A revision of the Brazilian species of Cordia subgenus Varronia (Boraginaceae). Notes from the Royal Botanical Gardens of Edinburgh 44: 105-140.

Taroda, N. \& Gibbs, P.E. 1987. Studies on the genus Cordia L. (Boraginaceae) in Brazil. 2. An outline taxonomic revision of subgenus Myxa Taroda. Hoebnea 14: 31-52.

Taroda, N., Melo, J.I.M. \& Silva, L.C. 2012. Boraginaceae. In: Cavalcanti, T.B. \& Silva, A.P. (Orgs.), Flora do Distrito Federal, Brasil 7: 47-67. Embrapa Recursos Genéticos e Biotecnologia. Brasília.

The IUCN Red List of Threatened species. 2001. IUCN Red List Categories and Criteria version 3.1. http://www.iucnredlist.org/ technical-documents/categories-and-criteria/2001-categories-criteria/

Thiers, B. 2014. Index herbariorum: a global directory of public herbario and associated staff. New York Botanical Garden's Virtual Herbarium. http://sweetgum.nybg.org/ih/ [continuously updated].

Weberling, F. 1995. Morphology of flowers and inflorescences. Cambridge University Press. Cambridge.

Associate Editor: Pablo Vargas Received: 7-V-2015

Accepted: 30-III-2016 